Turkish Online Journal of Qualitative Inquiry (TOJQI)

Volume 10, Issue 2, April 2019: 267-295

DOI: $10.17569 /$ tojqi.551484

Research Article

\title{
Investigation the Effects on School in the Frame of Educational Change Processes of a Technology Support for Hearing Impaired Students ${ }^{1}$
}

\author{
Lokman Şılbır², Hasan Karal ${ }^{3}$, Gülbahar Merve Çakmak Şılbır ${ }^{4}$, \\ Yasemin $\mathrm{Karal}^{5}$, Ekrem Bahçekapılı ${ }^{6}$
}

\begin{abstract}
The main purpose of this research is to examine the effects of a technology-based project (ALIS-T) for hearing impaired students on the educational change processes. This qualitative study, where the case study method was applied, was conducted in a hearing impaired primary school. Participants of the study consisted of a school administrator, a vice school administrator, thirteen teachers and the parents of four students in the 3rd and 4th grades. Semi-structured interviews, unstructured observations and documents were used as data collection tools, with data analyzed by descriptive and interpretive analysis. The findings are grouped under the personal change, internal change, and external change model, based on Goodson's educational change model. Teachers, who believe that the technology support is necessary in the education of the hearing impaired, are an important indicator of individual change during the project. The internal change have appeared in six different themes. These themes are respectively understanding of education, in-school interaction, change in school, teaching methods, the structure of school and school's success themes. Also, the external change category has appeared in three different themes. These themes are dissemination, cooperation and organization, and the political importance of the school themes.
\end{abstract}

Keywords: Hearing impaired education, Processes of educational change, Use of ICT

\footnotetext{
${ }^{1}$ This research is supported by The Scientific and Technological Research Council of Turkey (Project Number: TÜBITAK-113K717) The initial findings of the study were presented at the "3rd International Eurasian Educational Research Congress" held in Muğla (Turkey) on 31 May -3 June 2016.

${ }^{2}$ Res.Asst.Dr., Trabzon University, Fatih Faculty of Education, Department of Computer Education \& Instructional Technology, lokmansilbir@ktu.edu.tr, https://orcid.org/0000-0003-3655-2512

${ }^{3}$ Prof.Dr., Trabzon University, Fatih Faculty of Education, Department of Computer Education \& Instructional Technology, hasankaral@trabzon.edu.tr, https://orcid.org/0000-0002-3555-050X

${ }^{4}$ Karadeniz Technical University, gmerve.cakmak@ gmail.com. https://orcid.org/0000-0003-0321-7259

5 Asst.Prof.Dr., Trabzon University, Fatih Faculty of Education, Department of Computer Education \& Instructional Technology, yaseminkaral@trabzon.edu.tr, https://orcid.org/0000-0003-4744-4541

${ }^{6}$ Asst.Prof.Dr., Karadeniz Technical University, Faculty of Economics \& Administrative Sciences, Management Information System, ekrem.bahcekapili@ktu.edu.tr, https://orcid.org/0000-0002-7538-1712
}

Received: 09.04.2019, Accepted: 30.04.2019 


\title{
Teknoloji Desteğinin İşitme Engelliler Okulu Üzerindeki Etkilerinin Eğitimde Değişim Süreçleri Çerçevesinde İncelenmesi
}

\begin{abstract}
$\ddot{O} z$
Araştırmanın amacı, işitme engelli öğrencilere yönelik yürütülen teknoloji tabanlı bir projenin (İşitme Engelli Bireyler İçin Grafik Sembolleri Temel Alan Teknoloji ile Desteklenmiş Öğrenme Ortamları Tasarımı: ALISS-T) okul üzerindeki etkilerinin eğitimde değişim süreçleri çerçevesinde incelenmesidir. Durum çalışması yönteminin uygulandığı bu çalışma, 2014 - 2015 ve 2015 - 2016 eğitim öğretim yıllarında Doğu Karadeniz Bölgesinde yer alan bir İşitme Engelliler İlköğretim okulunda yürütülmüştür. Çalışmanın katılımcıları belirtilen okulda görev yapan bir okul müdürü, bir okul müdür yardımcısı, on üç öğretmen ve bu okulda 3. ve 4. sinıfta öğrenim görmekte olan dört öğrencinin velisinden oluşmaktadır. Veri toplama aracı olarak, yarı yapılandırılmış mülakatlar, yapılandırılmamış gözlemler ve dokümanlar kullanılmıştır. Veri toplama araçlarından elde edilen veriler betimsel ve yorumlayıcı analiz yoluyla analiz edilmiştir. Verilerin analizi sonucunda elde edilen bulgular Goodson'ın Eğitimde Değişim Süreçleri Modeli temel alınarak "Bireysel Değişim”, "İçsel Değişim” ve "Dışsal Değişim" olmak üzere üç kategori altında toplanmıştır. İşitme engelliler ilkokulunda teknoloji tabanlı olarak yürütülen projenin, okul üyelerinde meydana getirdiği bireysel değişimlerin, kişilerin projenin işitme engelliler eğitimindeki ihtiyacına yönelik inançları üzerinde meydana gelen değişimler olduğu görülmüştür. Teknoloji desteğinin işitme engelliler eğitiminde gerekli olduğuna inanan öğretmenlerin proje süresi boyunca bireysel olarak çaba göstermeleri bireysel değişimin önemli bir göstergesidir. İçsel değişimin, kişilerin eğitim anlayışlarında meydana gelen değişimlerin, okul içi etkileşimlerin yönünün, okul içinde oluşan değişimlerin, projenin öğretim yöntemlerine katkılarının, okulun yapısı ve nihayet tüm sürecin bir çıktısı olan okulun başarısı üzerindeki değişimlerden meydana geldiği görülmüştür. Dışsal değişim açısından ise projenin Milli Eğitim Bakanlığı'nın EBA sisteminde yer almasıyla okul içerisinde yürütülen teknoloji destekli eğitim öğretim faaliyetlerinin ülkedeki işitme engelliler eğitimine farklı bir boyut kazandırdığı anlaşılmıştır.
\end{abstract}

Anahtar Sözcükler: Iş̧itme Engelliler Eğitimi, Eğitimde değişim süreçleri, BİT kullanımı 


\section{Introduction}

School development and changes in education aim to plan and maintain appropriate educational environments by focusing on students' academic achievements and social skills (Çalık \& Er, 2014). Lodge and Reed (2003) stressed the need for schools to continuously focus on learning, emphasizing that schools need educational changes in order to respond to the expectations of the community. In the case of educational change, it is not right to talk about the change in technology or structure. Instead, the advancement of technology, process, structures, and systems, especially human factors, will be appropriate for the change (Balc1, 2000).

Fullan (1993) describes educational change as follows: In order to assist schools in achieving their goals, introducing a number of structures, programs or practices that are more effective than the existing system. Cohen (1996) expressed the role of ICT in educational change as follows: "Information and Communication Technology came as a revolution in knowledge. With the long-term use of ICT, new horizons and approaches will be created in the field of teaching and learning". J. Underwood and G. Underwood (1990) likewise predicted that the computer would be successfully integrated into classroom environments and that in the future it would increase educational opportunities. Based on these definitions and studies conducted in educational environments in recent years, it is possible to say that the use of ICT in schools has become widespread and the ICT has become functional in the learning-teaching process (Altun, 2006; Kırıkkaya, Dağ, Durdu \& Gerdan, 2016).

When the education of the hearing impaired is examined, it is seen that the academic success of the students depends on many variables such as family, teacher, school program and curriculum, as well as individual characteristics (Blackorby \& Knokey, 2006). While most of these students have educational difficulties in reading and writing, some adults cannot even reach a fourth grade reading level (Dillon, de Jong, \& Pisoni, 2012). Research conducted in both Turkey and other countries reached several general judgments to explain the causation of these findings. General education programs used in schools for the hearing impaired (Uzuner, İçden, Girgin, Beral \& Kurcaali-Iftar, 2005; Uzuner et al., 2011; Turnbull, Turnbull, Wehmeyer \& Shogren, 2013) 
- The education curriculum is language-based and focuses on providing direct language and contact information (Karchmer \& Mitchell, 2003)

- Limitations on communication with family (Turnbull et al., 2013)

- Lacking social cues from the surrounding: like talking (Cole, Cutler, Thobro \& Haas, 2009)

- Lack of adequate and appropriate training programs (Krestchmer \& Kretschmer, 1986; Uzuner et al., 2011)

- Disruptions in critical periods of language acquisition: model taking, imitation (Krestchmer \& Kretschmer, 1986; Marschark, Sapere, Convertino, Mayer, Wauters \& Sarchet, 2009)

- Lack of natural language input (Pınar, 2006; Tüfekçioğlu, 1998)

These factors, which are shown to cause the language skills of the hearing impaired to not improve, can be overcome with planned and systematic education services in the educational environment, tailored to the individual needs of the student. In addition to the verbal (oral) method and sign language traditionally used in the education of hard of hearing students, appropriate methods are being investigated to improve students' literacy and language development (Mayer \& Leigh, 2010). Technological tools are beneficial for teaching hearing impaired students who have problems learning by traditional methods (Shepherd \& Alpert, 2015; Snoddon, 2010).

The role of current educators is to design a learning environment suitable for the individual characteristics of hearing-impaired students and encourage their learning (Shepherd \& Alpert, 2015; Tüfekçioğlu, 1998). However, it is quite complicated to integrate technology into hearing impaired education, to overcome existing educational problems, and to ensure that schools adopt these processes of change in education. Educators therein have many tasks, such as choosing the technologies they will use in learning environments, to developing their existing mental, cognitive and affective skills In addition, tasks such as determining teaching methods, strategies, and resources and initiate change in education (Beycioğlu \& Aslan, 2010; Fullan, 1993). The educational change also has a comprehensive process, such as the adoption of a new system to be used in the school by both school members (management, teacher, student, family, staff), the school's stakeholders (ministry, governorship, municipality), and the students, to adapt to innovation (Çalık, 2003; Goodson, 2001; Stiggins, 2002). The factor 
critical to the success of the change in the structure of education is working simultaneously and in cooperation with internal and external stakeholders (Fullan, 1999). While considering these situations, it is seen that the educational change should involve a systematic and planned process.

Researchers trying to explain the systematic structure of the educational change processes have introduced models in this regard (Fullan, 2002; Goodson, 2001). In Goodson (2001), there are three types of changes in the processes of educational change: internal, external and personal change. Internal change refers to change activities within the school, external change relates to the changes affecting the whole education system, and personal change refers to changes in individuals' beliefs and ideas. (Figure 1).

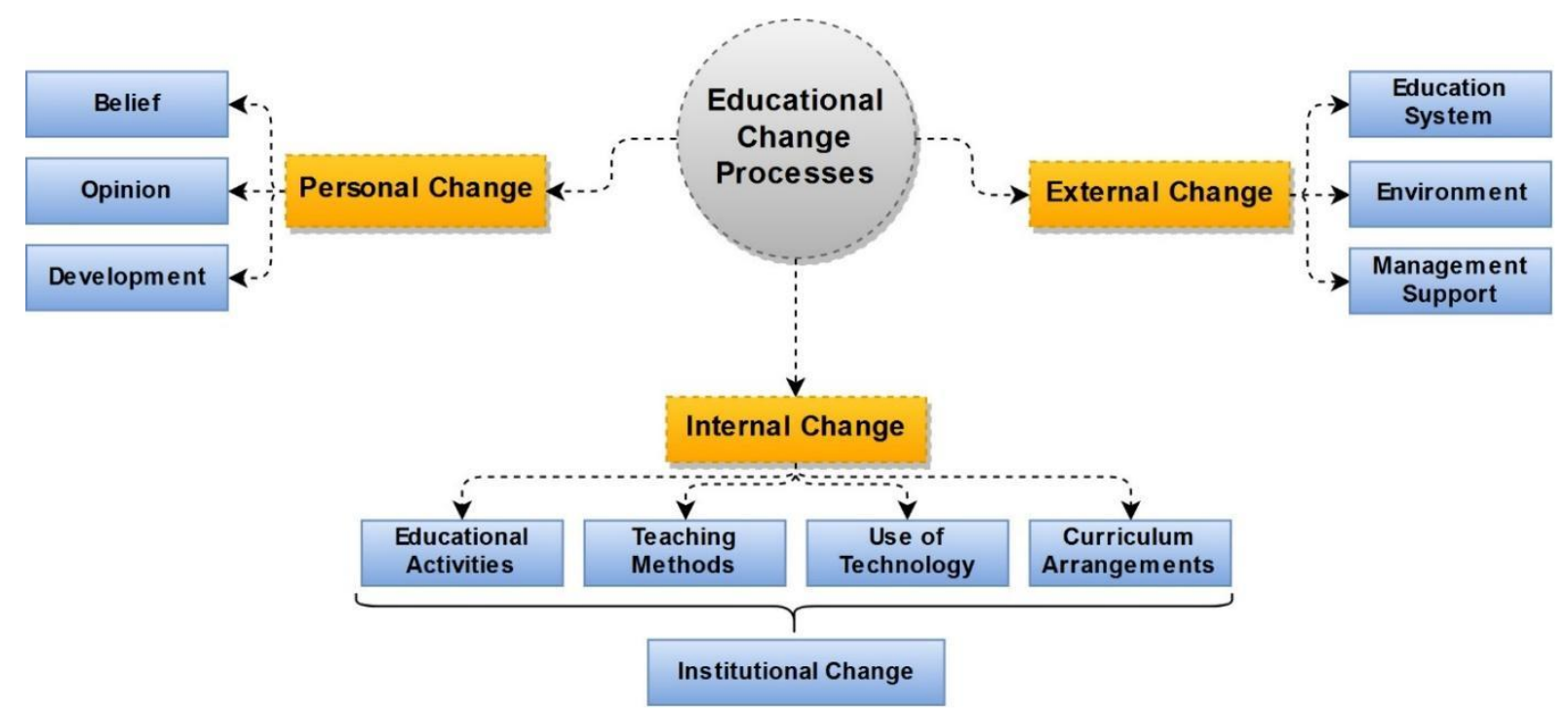

Figure 1. The model of educational change processes (Goodson, 2001)

In terms of change activities in the educational environment, Goodson says that the various educational activities carried out within the school have a complete impact on the education system and that the ideas, beliefs and attitudes of individuals within the school need to adapt to change. When internal, external and personal types of change are in equilibrium, it ensures the success of the change within the school. Notably, the perception of change in the individuals within the school and their efforts for change are essential regarding the educational change processes. In this context, the change activities should be carried out in a systematic working environment should be established between teachers, school management and school stakeholders (Fullan, 1999). 
To investigate the processes of change in the education of hard of hearing individuals, it is necessary to look at the elements that come to the fore in solving the educational problems of the students. These can be listed as (i) individual differences and special needs of hearingimpaired students, (ii) technology as a learning-teaching tool and (iii) learning materials in which visual elements are highlighted (Şılbır, 2011; Karal \& Çiftçi, 2008; Karal, 2014; Karal et al, 2014). It is clear that educators, researchers or teachers who successfully bring together these three elements will make a significant contribution to the educational environment of hard of hearing individuals.

The Alternative Communication System (ALIS-T) project is a system developed to solve the problems in the field of education of the hearing impaired. Starting from 2010 to 2016, the educational needs of the hearing impaired students were determined by the projects carried out sequentially, and technology-supported learning environments were developed with graphic symbols and used in the courses of hard of hearing students. With the project of ALIS-T supported by TUBITAK (113K717), the focus is on the inclusion of technology in the educational environment and the systematic structure to improve the students' successes by solving the problems experienced by the hearing impaired students in their education process. It is emphasized in the literature that innovative approaches are adopted, useful methods are used for education, and systems, where information and communication technologies are integrated with education, are necessary for the development of schools (Hopkins, 2001; Schein, 1992). Hence, the main purpose of the study is to examine the effects of the technologybased ALIS-T project on hearing-impaired students within the framework of the educational changes processes. For this purpose, the following research problems will be sought in the study:

1. What are the impacts of the technology-based project for hard of hearing students on individual changes in school members?

2. What are the effects of the technology-based project for hard of hearing students on the internal change of the school?

What are the effects of the technology-based project for hard of hearing students on the external change of the school organization? 


\section{Methodology}

Qualitative research used in the field of special education plays an essential role in understanding the current situation, providing a conceptual framework for natural events and analyzing the facts in detail (Obiakor \& Rotatori, 2010). It was stated by Brantlinger et al. (2005) that qualitative research provides researchers with an opportunity to understand the essential nature of the phenomenon and follow a systematic approach. For this reason, the qualitative research approach is used in this study. The process of collecting data in qualitative research is a very important and time-consuming process. Describing the situation in detail, understanding the behavior of people and conducting analyzes by ethical principles require an extended period (Shank, 2006). In this context, when the purpose of the study is taken into consideration, the case study method, one method of qualitative research, has been used for detailed and in-depth follow-up to the researched situation. Considering the possibilities of the case study method, such as looking at a situation from different angles, using different data collection techniques and investigating the situation in detail, is thought to be helpful in explaining research problems.

\section{Participants}

Participants in this study were selected by the purposeful sampling method, taking into consideration the theoretical framework of the study, the purpose of the research and the research problems. Patton (2002) refers to the diversity of purposive sampling methods and discusses the existence of 16 different purposeful sampling methods. Maximum diversity sampling, which is one of the sampling methods of Patton (2002), was determined as the type of purposive sampling methods in this study. According to this method, participants are of a wide variety with the researcher aiming to investigate commonalities and patterns therein.For this purpose, not only one group but many individuals were included in the study to ensure the maximum variety of individuals from the school in the selection of the study group.

The participants of the study consisted of 1 principal, one principal assistant and 13 teachers working in a Hearing Impaired Primary School and four parents. School administrators and school vice administrators coded in A1 and A2, teachers' coded in from Ö1 to Ö13, and student 
parents coded from P1 to P4. It was observed that 6 of the teachers (T1, T2, T11, T12, T13) in the study group applied the project on demand and two teachers (T3, T4) carried out the courses on the project. The other teachers were selected from the teachers who did not use the project applications in their lessons but had information about what the project was and how it was conducted.

\section{Data Collection Instruments}

During the data collection process, semi-structured interview, unstructured observation, and document analysis techniques were used. The semi-structured interviews were conducted with the school principal, vice principal, teachers, and parents. The focus of the questions used in the interviews was based in literature on the framework of educational change processes. In this context, the scope of the interview questions addressed personal change, internal change, and external change areas, which are frequently mentioned in research on change processes in education. The educationists considered these participant groups in preparing questions to be used during the interviews. The interview questions were presented to the participants one day in advance, and a pilot study was conducted. After the pilot study, new questions were added to the interview questions to get more detailed answers.

The unstructured observations were made by the researchers who carried out doctoral and graduate studies within the scope of the project. The researchers, as participant observers, made observations in project implementation classes and the school. An observer role as participant refers to a person who does not interact with the observers in the observed environment but is known by the group in which he/she is a researcher (Büyüköztürk, Kılıç-Çakmak, Akgün, Karadeniz \& Demirel, 2010). The purpose of the unstructured observation technique is to provide the observer with the freedom to collect and record information (Büyüköztürk et al., 2010). In this context, the researchers made notes by writing, taking photographs, taking video recordings or recording their voice during observations carried out in the school.

Finally, the documents obtained during the research consist of 2015-2019 Strategic Plan of the hearing impaired primary school, notes written by the parents to the teacher, the material suggestions of the teachers individually prepared for the project, published news in various media organizations (TRT News, internet news, activity news posted on the websites). 


\section{Data Analysis}

The qualitative data obtained through interviews and observations were analyzed through descriptive analysis. The descriptive analysis approach is defined as analyzing the data within the framework of the themes determined in the research questions (Yıldırım \& Şimşek, 2005). In order to avoid data loss in the analysis of the data, the statements transferred to the text should be measured and discussed by several experts (Milne \& Adler, 1999). In this respect, interview records and observation notes obtained by the research problems of the study were read and analyzed by two experts from the project team. In the analysis process, the transcript of the data, open coding, core coding, inter-code compliance (0.89), theme and direct quoting were followed. In this process, a qualitative data analysis program called MAXQDA (C) was also used. The documents were analyzed according to the personal, internal and external change categories discussed in the framework of the research and analyzed by interpretive analysis. As a result of coding of the data and comparing it with other data, the documents which are in accordance with the relevant category are presented under the categories in the findings section and related to the findings obtained from other data.

\section{Findings}

In this part of the study, the findings obtained from the analysis of the obtained data are presented. In this context, the findings are given under the main categories of Personal Change, Internal Change, and External Change, based on research problems. Data collection tools, the themes related categories and main categories are presented in Figure 2 with a conceptual network. 


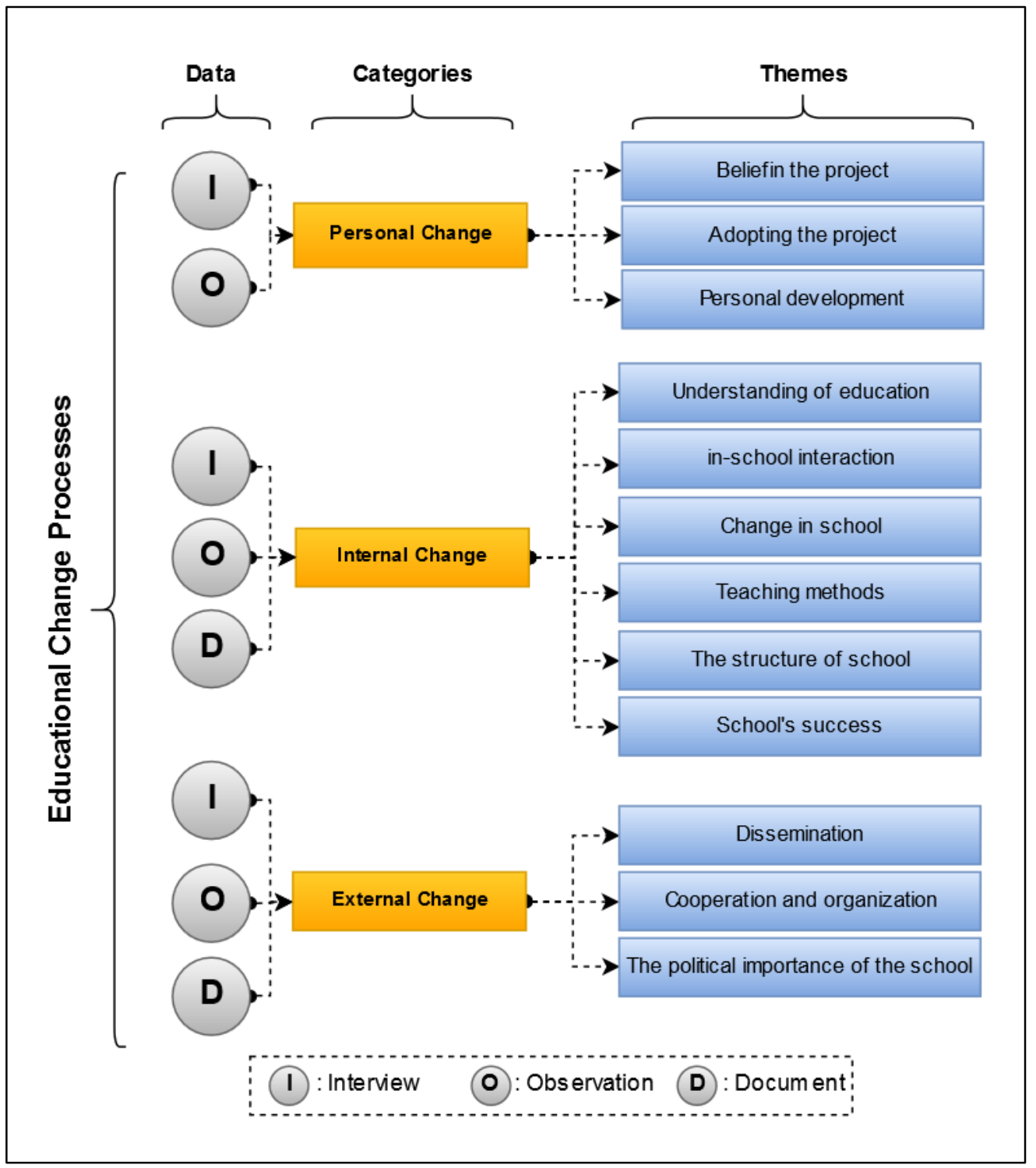

Figure 2. The conceptual network of educational change processes.

As a result of interviews with teachers, school management and parents about the technologybased project conducted for hearing impaired students, it is seen that the changes of the project on individuals are collected in belief in the project, adopting the project and personal development titles. Within the scope of internal change category, it is seen that internal changes of the school are grouped under educational understanding, in-school interaction, change in school, teaching methods, the structure of school and success of the school headings. It is seen that the external changes of the school organization are grouped under dissemination, cooperation, and organization and the political importance of the school headings. 


\section{Findings Related to Personal Change Category}

The category of personal change is discussed in three different themes. These themes are, respectively, belief in the project, adopting the project and personal development themes. Themes, sub-themes and participant codes for each theme are listed in Table 1.

Table 1

Findings Related to Personal Change Category

\begin{tabular}{|c|c|c|c|}
\hline Category & Theme & Sub Theme & Participants \\
\hline \multirow{10}{*}{$\begin{array}{l}\text { Personal } \\
\text { Change } \\
\text { Category }\end{array}$} & \multirow{4}{*}{$\begin{array}{l}\text { Belief in the } \\
\text { project }\end{array}$} & Belief to the dissemination of the project & $\begin{array}{l}\text { T2, T3, T4, T6, T10, T11, T12, } \\
\text { T13, A1, A2, P2 }\end{array}$ \\
\hline & & Contribution to students' education & $\begin{array}{l}\text { T1, T2, T4, T5, T6, T8, T9, T10, } \\
\text { T11, T12, A1, A2, P3 }\end{array}$ \\
\hline & & $\begin{array}{l}\text { Bringing innovation to the educational } \\
\text { environment }\end{array}$ & $\begin{array}{l}\text { T2, T3, T4, T6, T7, T10, T11, } \\
\text { T13, P3, P4 }\end{array}$ \\
\hline & & Benefits of using graphic symbol & T1, T3, T11, T12, T13 \\
\hline & \multirow{2}{*}{$\begin{array}{l}\text { Adopting the } \\
\text { project }\end{array}$} & Willingness to contribute to the project & $\mathrm{T} 2, \mathrm{~T} 8, \mathrm{~T} 11, \mathrm{~T} 12$ \\
\hline & & Use of project products by other classes & T5, T11, T12 \\
\hline & \multirow{4}{*}{$\begin{array}{l}\text { Personal } \\
\text { development }\end{array}$} & $\begin{array}{l}\text { Personal development of practice } \\
\text { teachers }\end{array}$ & T4, T5, T8, T10, T13 \\
\hline & & Development in students & $\begin{array}{l}\text { T2, T3, T4, T5, T11, } \\
\text { T12, T13, A2 }\end{array}$ \\
\hline & & Attendance & $\mathrm{T} 3, \mathrm{~T} 5, \mathrm{~T} 11, \mathrm{P} 2, \mathrm{P} 4$ \\
\hline & & Transfer to daily life & P3, P4 \\
\hline
\end{tabular}

When Table 1 is examined, it is seen that the category of individual change is divided into three main themes. Sub-themes related to the theme of belief in the project have been shaped in these subjects: belief to the dissemination of the project, contribution to students' education, bringing innovation to the educational environment and benefits of using the graphic symbol. Based on the data obtained from the interviews, it is seen that the participants believe that the project should be developed and applied to both primary and secondary school levels and in other handicapped groups should be use this system for their education. T2 stated the views on this subject as follows:

"although ALIS appears only to address the hearing impaired, ALIS is a system that can be used for students with learning disabilities, students with low intelligence levels and students with attention problems". (T2)

There is a change in the opinions of the participants about the contribution of the ALIS project to the education of the students. Expressing that students' sentence building skills increase, A1 
Investigation the Effects on School in the Frame of Educational Change Processes of a Technology Support for Hearing Impaired Students

believes this is a great success for students. In this respect, the views of A1 are as follows: “...for example, you are aware that students learn concepts better, for instance, in making sentences. Some students can create a sentence of 3-4-5 words. This is a great success...". In the classroom observations, it was determined that a student with a low literacy level compared to his classmates had, with the project implementations, achieved almost grade level literacy, and that there was an increase in course attendance, interest, and motivation. During interviews participants suggested their beliefs that the project implemented in the hearing impaired elementary school brought innovation to the educational environment.

The sub-themes of the theme of adopting the project are the willingness to contribute to the project and use of project products by other classes. T12's desire to contribute to the project is expressed in the following words: "...because I care about the project, I felt responsible for its development. The school also gave importance to the project...".

Depending on the theme of individual development, it is seen that sub-themes are shaped in the personal development of practice teachers, development in students, attendance, and transfer to daily life subjects. It was stated by the participants that on the teachers who applied the ALIS-T project had individual development. In this regard, the views of T10: "...I saw the development of Turkish branch teachers. There's a lot of progress...". Other participants stated a similar situation. It was stated by the participants that the ALIS-T project created a change on the students. T4 stated his opinions on this subject as follows:

"our lessons were much more enjoyable because of the animation. Students increased the demand for the course. As soon as the animation was opened, the students were motivated. They started to form a sentence". (T4)

It was also observed by the observer that the students were willing to participate in the lessons with the ALIS-T project applications. On the other hand, it was stated by the parents of students that there was an increase in the students' desire to go to school, while their desire to go to rehabilitation centers decreased. Also, the parents of the students stated that the students started to transfer the information they learned to daily life. V2 stated his views on this subject as follows: “...there's been a lot of progress since the project started. This year is much better. Now he knows the objects and answers them well...". 


\section{Findings Related to Internal Change Category}

The internal change category is discussed in six different themes. These themes are respectively, understanding of education, in-school interaction, change in school, teaching methods, the structure of school and school's success themes. Themes, sub-theme and participant codes for each theme are listed in Table 2.

\section{Table 2}

Findings Related to Internal Change Category

\begin{tabular}{|c|c|c|c|}
\hline Category & Theme & Sub Theme & Participants \\
\hline \multirow{20}{*}{$\begin{array}{l}\text { Internal } \\
\text { change }\end{array}$} & \multirow{3}{*}{$\begin{array}{l}\text { Understanding of } \\
\text { education }\end{array}$} & Regulation of teaching plans & T2, T3, T4, T6, T11 \\
\hline & & Dictionary provided with graphics & $\mathrm{T} 1, \mathrm{~T} 2, \mathrm{~T} 3, \mathrm{~T} 4, \mathrm{~T} 11$ \\
\hline & & Planning to use in different branches & $\begin{array}{l}\text { T2, T5, T6, T9, T11, T12, } \\
\text { T13 }\end{array}$ \\
\hline & \multirow{3}{*}{$\begin{array}{l}\text { in-school } \\
\text { interaction }\end{array}$} & $\begin{array}{l}\text { Exchange of ideas within the school about } \\
\text { the project }\end{array}$ & $\begin{array}{l}\text { T1, T3, T4, T9, T11, T12, } \\
\text { T13, M1 }\end{array}$ \\
\hline & & School support to the project & $\begin{array}{l}\text { T1, T3, T4, T6, T7, T11, } \\
\text { T12, T13, M1 }\end{array}$ \\
\hline & & Interpersonal communication & T3, T11 \\
\hline & \multirow{3}{*}{ Change in school } & Change observed in classrooms & $\begin{array}{l}\text { T1, T2, T3, T4, T11, T12, } \\
\text { M1, M2 }\end{array}$ \\
\hline & & Efficient use of time in teaching & T1, T3, T5 \\
\hline & & Change observed at school & T5, M1 \\
\hline & \multirow{7}{*}{ teaching methods } & Use of graphic symbols in teaching & $\mathrm{T} 1, \mathrm{~T} 2, \mathrm{~T} 4, \mathrm{~T} 5, \mathrm{~T} 11$ \\
\hline & & Use of animations in teaching & $\mathrm{T} 1, \mathrm{~T} 2, \mathrm{~T} 4, \mathrm{~T} 5, \mathrm{~T} 11$ \\
\hline & & Concretization of abstract concepts & $\mathrm{T} 2, \mathrm{~T} 9, \mathrm{~T} 11, \mathrm{M} 2$ \\
\hline & & Using interactive games in repeating work & $\mathrm{T} 1, \mathrm{~T} 2, \mathrm{~T} 3, \mathrm{~T} 4, \mathrm{~T} 13$ \\
\hline & & Use in student evaluation studies & $\mathrm{T} 1, \mathrm{~T} 3, \mathrm{~T} 4, \mathrm{~T} 12$ \\
\hline & & Use in reading and writing & $\begin{array}{l}\text { T1, T2, T3, T4, T5, T11, } \\
\text { T13, M2 }\end{array}$ \\
\hline & & $\begin{array}{l}\text { The proximity of teachers to current } \\
\text { teaching methods }\end{array}$ & $\mathrm{T} 2, \mathrm{~T} 3, \mathrm{~T} 5, \mathrm{~T} 13$ \\
\hline & \multirow{2}{*}{$\begin{array}{l}\text { The structure of } \\
\text { school }\end{array}$} & Technical infrastructure & T5, T12, M1, M2 \\
\hline & & Physical Infrastructure & $\mathrm{T} 4, \mathrm{~T} 8, \mathrm{M} 1$ \\
\hline & \multirow{2}{*}{ School's success } & Students' academic achievements & $\begin{array}{l}\text { T3, T4, T5, T10, T12, M1, } \\
\text { M2, V2 }\end{array}$ \\
\hline & & Social skills of students & $\begin{array}{l}\text { T1, T3, T4, T11, T12, T13, } \\
\text { M2 }\end{array}$ \\
\hline
\end{tabular}

When Table 2 is examined, it is seen that the sub-themes related to the theme of understanding of education are shaped within the framework of regulation of teaching plans, dictionary provided with graphics and planning to use in different branches titles. The participants also shared their opinions about the planning of the instructional plans and the idea that the project 
should be included in the school's annual plans, and that the graphic symbols, which are the basis of the project, could form a common language among the students. In this regard, T1 stated the following views: "...A standard dictionary for our students. Symbols have been standardized and speeded up children's use of the word. Words didn't feel the same in children, but symbols helped us to overcome this obstacle. I saw the benefit of the project...". Finally, it is seen that teachers make plans to use the project products outside of Turkish, Mathematics and Life Science courses. Also, in the observation data, apart from the project implementation teachers, T12 has used project outcome in their own courses. In the documents obtained within the scope of the research, it was seen that the material that $\mathrm{T} 12$ prepared with the $5 \mathrm{~N} 1 \mathrm{~K}$ method using the project products supports this situation (Figure 3).

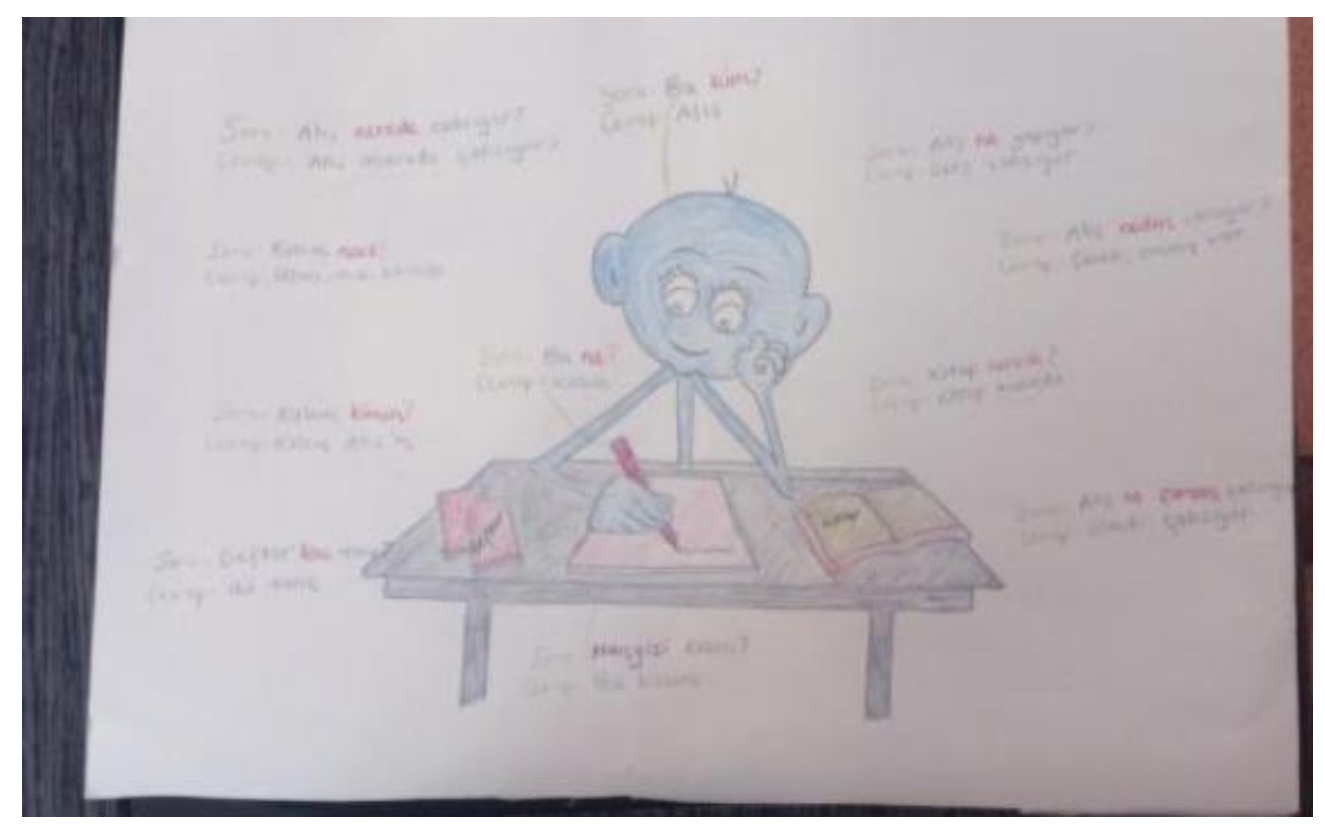

Figure 3. Material developed by T12 using project applications.

It was determined that the school management and teachers exchanged ideas about the application and development of the project. A1 expressed his views in this regard: "...we often speak between us. We have different ideas that we are trying to make something different about it. I hope it will be even better in the future...". In observations by the observer during the implementation of the project, it was determined that teachers exchanged ideas about project products. In this exchange of ideas between teachers, it was seen that the application teachers were consulted by the other teachers about the project and the ideas were exchanged about how to follow the project products to their courses. It was also stated by the participants that the 
school administration encouraged both project activities and teachers to implement the project. Another aspect of the project's interactions within the school is the increase in communication among students, the students' starting to create sentences between each other and the rise in the share of the students in the two different classes.

It is seen that the sub-themes related to the theme of in-school interaction are shaped within the framework of the exchange of ideas within the school about the project, school support to the project, and interpersonal communication titles. There is a common belief that there is a positive change in the class of the participants in the project implementation classes and in the classes that apply the project products voluntarily. In addition to this, it was stated by the participants that the project applications were in a practical structure and the teacher saved time by providing efficient use of time in teaching. In this regard, T3 stated his views as follows:

"to tell the truth, the material comes are ready. The teacher does not spend much effort. We're just wasting effort while telling the content. It was necessary to add drama beforehand, but it is not necessary because it is ready. Reduced the teacher's burden. This system was beneficial to the teacher". (T3)

With the project related to the observed change in the school, opinions have been obtained that a positive atmosphere is formed within the school. A1 expressed his views as follows:

"there was a vitality in school. Due to the project, we did some activities, and both our activity and the participation of the project became different activities. I mean, I believe it brings vitality to school. The project also brought vitality to our teachers". (Al)

Also, in the findings obtained from the documents related to the sub-theme of the change observed in the school, it is seen that the project is seen as an opportunity for the school in the Strategic Plan of the school and that the institution will progress towards becoming a model school in the future.

It is seen that the sub-themes formed within the framework of the teaching methods are merged under the title of innovations of project products for the education of hard of hearing. The closeness of graphic symbols, animations, interactive games, rework studies, evaluation studies, reading and writing exercises, and all of these methods used in ALIS project to teachers' current teaching methods has become prominent. Participants emphasized that such 
environments are useful for the education of hard of hearing students. In the classroom observations, it was seen that project applications were beneficial in terms of teaching methods. Figure 3 presents an image of the use of interactive games accompanied by teachers.

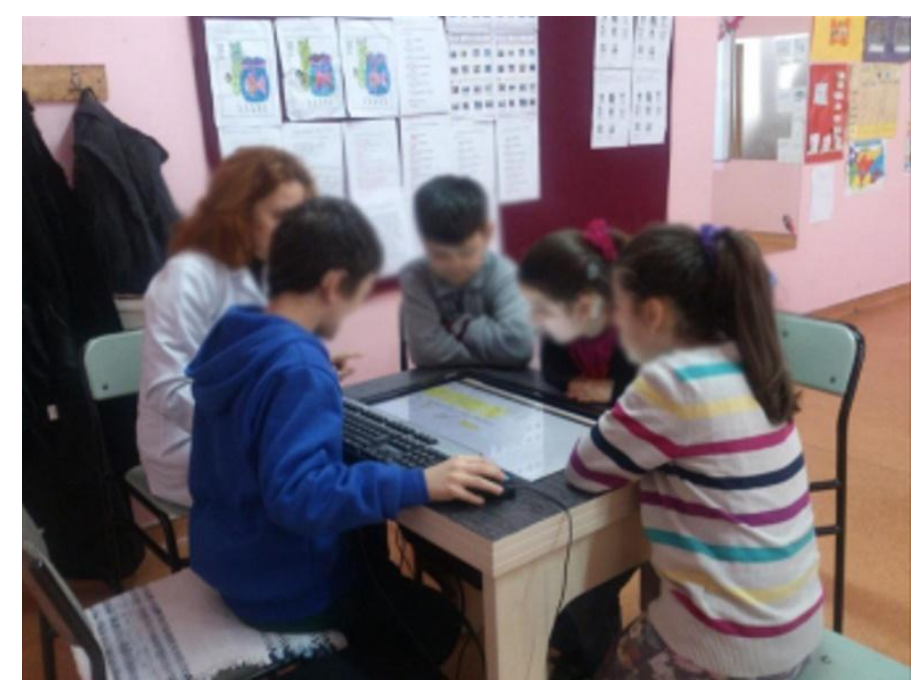

Figure 4. An image of interactive gaming applications

Headings in technical and physical infrastructure examined under the theme of the structure of the school show that there is a change in the project both technically and physically within the school. In addition to the technical support provided to the school for the project implementations, the fact that teachers equip the school corridors with the graphic symbols included in the project shows that their physical infrastructure is strengthened too (Figure 4).
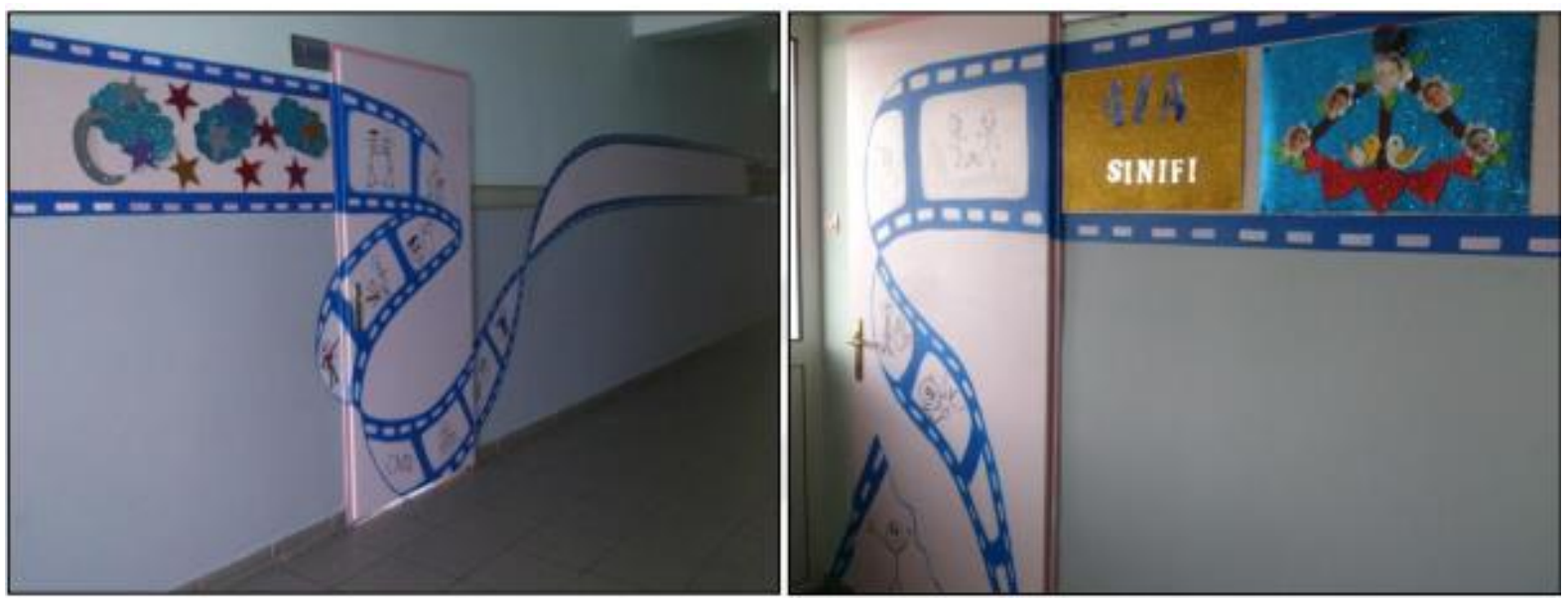

Figure 5. Images created in the 3rd and 4th class doors of painting works created using graphic symbols. 
It was observed that there was an increase in both the academic and social skills of the students about the success of the school. Participants stated that students generally came to the fore in subjects such as sentence formation, literacy, an increase in vocabulary. Also, it was also stated that students contributed to their communication skills and the students tried to make communication by establishing sentences with each other. In this regard, T1 stated his opinions as follows: "...I think it helps students express themselves. During the playtime, I observed the help of project for a student (a 4th class student) ...".

\section{Findings Related to External Change Category}

The external change category is discussed in three different themes. These themes are, respectively, dissemination, cooperation and organization, and the political importance of the school themes. Themes, sub-theme and participant codes for each theme are given in Table 3.

Table 3

Findings Related to Category of External Change

\begin{tabular}{|c|c|c|c|}
\hline Category & Theme & Sub Theme & Participants \\
\hline \multirow{7}{*}{$\begin{array}{l}\text { External } \\
\text { Change }\end{array}$} & \multirow[t]{2}{*}{ Dissemination } & $\begin{array}{l}\text { Dissemination activities throughout the } \\
\text { country }\end{array}$ & $\begin{array}{l}\text { T1, T3, T4, T5, T13, } \\
\text { M1 }\end{array}$ \\
\hline & & Raising awareness about the project & T1, T2, T5, T9, T13 \\
\hline & \multirow{3}{*}{$\begin{array}{l}\text { Cooperation and } \\
\text { organization }\end{array}$} & University-school cooperation & $\begin{array}{l}\text { T1, T2, T3, T4, T5, } \\
\text { T11, T12, M2 }\end{array}$ \\
\hline & & School-family cooperation & T2, T3, V2, V3, V4 \\
\hline & & University-school-family cooperation & $\mathrm{M} 1, \mathrm{M} 2$ \\
\hline & \multirow{2}{*}{$\begin{array}{l}\text { The political } \\
\text { importance of } \\
\text { the school }\end{array}$} & Top management's support & T4, M1, M2 \\
\hline & & School's recognition & $\mathrm{T} 4, \mathrm{M} 1$ \\
\hline
\end{tabular}

Table 3 shows that sub-themes related to the theme of dissemination are shaped under the titles of dissemination activities throughout the country and raising awareness about the project. Participants have given various views on the expansion of the project to include the country as a whole. Similarly, it was stated by the participants that the project should be used in all Hearing Impaired Primary Schools in the country. In this regard, the comments of Ö5 are as follows: "...I think other hearing impaired primary schools should be aware of this project and start practicing...". Based on the observation data, it was seen that various activities were carried out within the school for the dissemination of the project. In this context, one of the essential 
dissemination activities observed in the school is the demonstration of the project activities carried out in the school on National News channels (Figure 6).

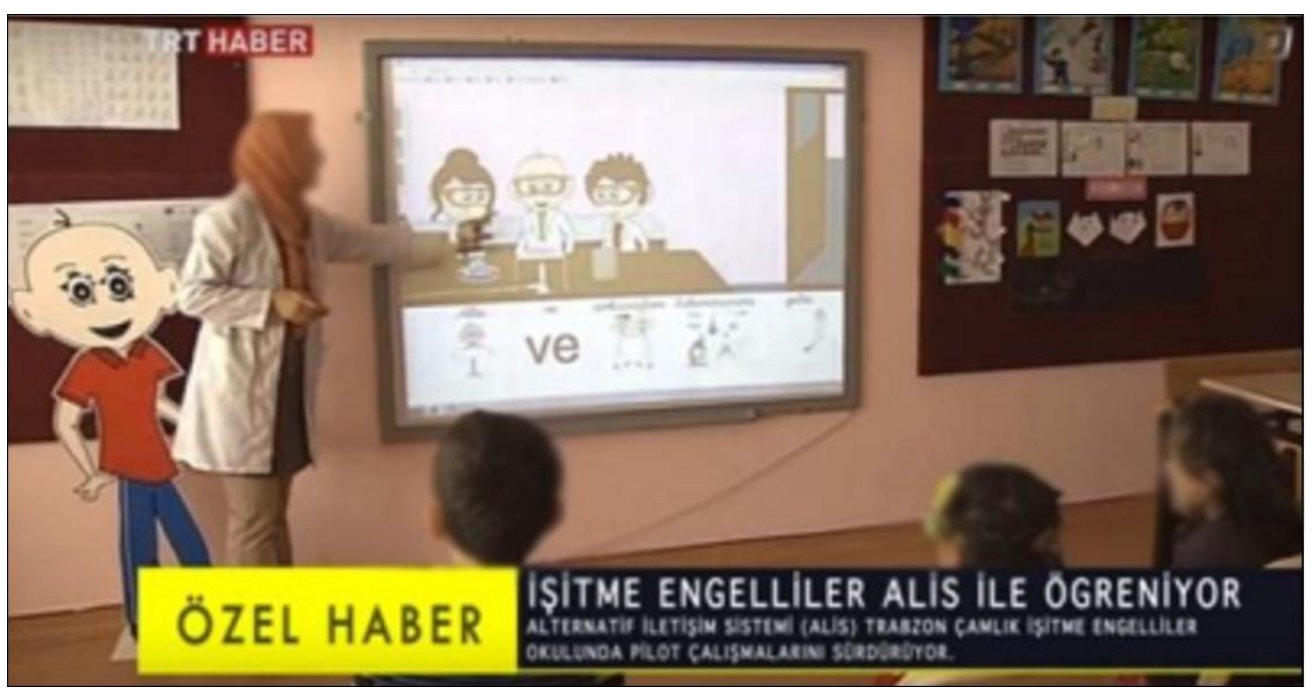

Figure 6. Project's broadcast on a national channel.

For the dissemination of the project, the media developed under the project were published in the Education Information Network platform of the National Education Directorate. In this context, a protocol was signed between the project executives and the Directorate of National Education Directorate of Special Education and the project's product was provided to all hard of hearing people.

In the context of cooperation and organization theme, it is seen that sub-themes are shaped in university-school cooperation, school-family cooperation, and university-school-family cooperation. It is emphasized by the participants that university, school, and family cooperation are essential for the implementation of project applications. A1's views are as follows:"...we also made evaluations of ALIS with our parents and teachers at each meeting. Both the researcher and the teacher are critical to us...". The contribution of the parents to the project, the documents, and observations obtained are supported this situation. This is stated in a letter written by A3 to T3. Finally, it is understood that the school has strengthened its relations with the environment and sets an example for other schools with project implementations. In this regard, T4 stated his views as follows:"...The project contributed a lot to the promotion of the school. This was proof that students could succeed. It was a good example among the other hard of hearing students...". 


\section{Discussion and Conclusion}

This study was carried out to examine a technology based project carried out for hearing impaired students within the framework of the educational change processes. In this section, the effects of the technology-based project on school members' individual changes, the general structure of the school (internal) and external change of school organization are discussed, and the results and recommendations are presented.

\section{The Effects of a Technology-Based Project on Individual Changes of School Members}

In the personal change, which is a form of educational change, the changes in the ideas and beliefs of the people in the education organization are discussed (Goodson, 2001). Kondakci (2005), in his study on the effect of the change on individuals, emphasized that individuals' readiness for change to have some effects on individual change. In this study, it is seen that the project, which is carried out in technology school in the school for the hearing impaired, is more likely to be seen on the personal changes of the members of the school, in their belief to the project, their adoption of the project and their personal development. In this context, when the literature is examined, Goodson (2001) states that individual change needs to be addressed in the context of changes in individuals' beliefs, opinions, and personal development. Also Sheehy (1981) states that the adoption of change will take place with an internal change in the beliefs and plans of individuals.

Awbrey (2005) stated that the changes on the values and beliefs of the individuals in the schools in terms of the success and the sustainability of the change, depend on the adoption of the ideas about the necessity of this change. From this point of view, it can be said that the individual change taking place in the processes of change in education is a complicated process. Teachers' beliefs about the need for the project implemented in the hearing impaired primary school, enables individual efforts. Based on this finding, it can be said that the individual changes of the members of the educational institutions should not be ignored in order to achieve success in the change studies.

The beliefs of individuals in the educational activities carried out within the school are the key to the success of the educational changes (Goodson, 2001). At this point, Fullan (2002) 
Investigation the Effects on School in the Frame of Educational Change Processes of a Technology Support for Hearing Impaired Students

emphasizes the importance of the possible change in the beliefs of individuals and asserts that the change of beliefs is difficult to achieve, but the change in the beliefs of individuals is vital for the processes of educational change. From this point of view, changes in the beliefs of the members of the activities carried out within the scope of the research have been carefully determined. In this context, it is understood from the findings of the research that individuals have positive beliefs towards the project that the project should be widespread, students contribute to their education, bring innovation to educational environments, use of graphic symbols, and benefit the parents. From this point of view, it can be said that technology-based educational activities cause a change in the beliefs of individuals in the application school.

In the study conducted, it was seen that the school administration, especially the school principal, had high faith and expectations. The fact that the school director's belief and expectation for the project is high enabled the teachers to participate in the project and work devotedly. At this point, it is stated that administrators working in special education schools have important tasks such as creating an interactive environment within the school and pushing teachers to research and study according to students learning needs (DiPaola \& WaltherThomas, 2003).

Teachers may find it difficult to respond to changing student needs, emerging technology, and socially emerging innovation. the teacher has a great deal of responsibility regarding improving himself/herself and acting by the necessity of educational change (Harris, 2008). So much so that the scientific studies that ignore the personal development of the teacher are difficult to reach success (Goodson, 2001). At this point, teachers in the school where the study was conducted believed in integrating project applications into their courses as they realize that change is a necessity, to solve problems that arise during applications, and to improve themselves professionally. As a result, it has been observed that the individuals in the project implementation school are open to innovation and show willingness for development in their personal behaviors and beliefs and attitudes towards project applications in this process. In this context, it has been seen that project implementations lead to changes in the individuals in the application school, their belief in the project, their adoption of the project and their individual development. 


\section{The Effects of a Technology-Based Project on Individual Changes of School Members}

In the study conducted, it was seen that the changes in the academic success and social skills of the students with technology supported environments gained an accelerating momentum. There are a lot of studies that will provide the students with the help of technology-supported learning environments to solve the communication problems experienced in the hard of hearing (Bayrakdar \& Çuhadar, 2015; Çiftçi, 2009; Girgin, Çoklar, Kurt \& 2009; Ş1lbır, 2011; Karal et al., 2014; Karal, 2015). In these studies, it has been seen that technology is a useful tool for the solution of the problems experienced by the students and they can increase the success of disabled students when used correctly.

Today, schools are expected to be aware of innovations and opportunities and to have an identity that creates environments to work in cooperation (NSBA, 2003). The dimension of internal change that deals with the general structure of the school are seen in many fields ranging from the cooperation of teachers and administrators in the school, communication between school members, in educational activities carried out in the school, in-class change, family and planning effective learning and teaching methods. From this point of view, the versatility which arises in relation to the change category within the school is also thought to be the source of the changes in the future education systems.

In this study, it has been shown that change has an effect on all members of the organization and has entered a planned change in the educational activities of the school with the solution of the problems in the current educational environment. The educational facilities in the current structure of the school should provide an environment that facilitates educational activities. At this point, it is essential in the study that the physical and technological infrastructure of the school is organized or procured according to educational activities regarding the success of the educational change processes (Erdoğan, 2012; Yalçın-Tepe, 2015). It was thanks to the coordinated work of the project team and the school members that the necessary infrastructure and support for the project applications affected the internal transformation processes of the school.

School members' participation in decisions in education processes is seen as an important factor affecting change in schools. Salvason (2005) states that the participation of teachers in the 
Investigation the Effects on School in the Frame of Educational Change Processes of a Technology Support for Hearing Impaired Students

education environment has a positive effect on the acceptance of change in schools, whereas, in a contrasting situation, the sense of responsibility and therefore the cooperation towards the implementation of the decisions made by others is decreasing. Aksoy (2005) states that school administrators are authoritative to keep communication channels active and to convince teachers, parents and other staff to change in the process of change. The key point in this situation is the school administration. Kaya (2013), in his study, states that school administrators are generally the ones who manage change but are not affected by the change processes. However, this study shows that the school principal's attitude towards change affects both the change in school and the individual change of the principal. While the manager took an active role in school-related activities in order to create an impact on individuals, it was observed that the change in the school was also affected him/her too. This result does not coincide with the finding of Kaya (2013).

\section{The Effects of a Technology-Based Project on Individual Changes of School Members}

As the environment has external effects on the changes in the school, the changes in the school also have an impact on the environment. On this subject, Hargreaves and Fullan (1998) state that schools cannot live separately from their environment. In the project carried out in the hearing impaired primary school, the school organization developed ideas for the dissemination of the project. It is known that the support of the senior management is important in the promotion of the school. In this respect, Sağ (2003) emphasized the importance of politicians to support the process because it educates individuals who protect both the culture of the society and those who are open to innovation. At this point, the support given to the project by the Governorate and the National Education Directorate accelerated the change process in education and played an encouraging role on the external change of the school. In addition, the promotion of the project within the school through the media has made a difference in terms of the recognition of the school. The school organization also conveyed this awareness to the change process positively. The Ministry of National Education's participation in the EBA system, which includes educational materials, is an important support for the dissemination of the project. In this way, the technology supported education activities carried out within the school have brought a different dimension to the education of the hearing impaired in the country. 
The fact that the school principal is open to change, supports teacher the development and shows a solution-oriented attitude to the problems in education is seen as important in the change processes (Goddard \& Bohac-Clarke, 2007). The process of change in education has a comprehensive and comprehensive process that requires the new system to be used at school (school, teacher, student, family, staff), school stakeholders (ministry, governorate, municipality), and students to adapt to innovation (Çalık, 2003; Goodson, 2001; Stiggins, 2002). As a result of this study, it was seen that educational change processes were affected by many different subjects.

Considering the results of the research and literature review, it was observed that the opinions of the school administrators, teachers, and parents in the planning of change for the education of the hearing impaired was related to the successful outcome of the change. Especially in studies aimed at hearing impaired students, teachers' teaching methods should be examined, and appropriate plans should be made by the education concept that is dominant in the school. Also, training activities should be promoted with various media organizations to increase the interest of the individuals in the school towards the change activities carried out. In addition, taking the support of the senior management may cause changes in the perspectives of the people. In future studies, determining the level of influence and the relationship between the three main categories of educational change processes can be useful in understanding the processes of change. 


\section{References}

Aksoy, B. (2005). Bilgi Teknolojisinin Yarattığı Örgütsel Değişim: Nasıl Bir İnsan Kaynakları Yönetimi?. Bilgi Dünyast, 6(1), 58-77. Retrieved 12, January, 2015, from http://bd.org.tr/index.php/bd/article/view/188/170.

Altun, T. (2006). Evaluating the impact of information and communications technology (ICT) on the culture of school: strategies and implications for teacher education. Ahi Evran Üniversitesi Kırşehir Eğitim Fakültesi Dergisi, 7(2). Retrieved 15, April, 2016, from http://dergipark.gov.tr/download/article-file/15663.

Awbrey, S. M. (2005). General education reform as organizational change: The importance of integrating cultural and structural change. The Journal of General Education, 54(1), 121. DOI: http://dx.doi.org/10.1353/jge.2005.0012.

Balc1, A. (2000). İkibinli yıllarda Türk milli eğitim sisteminin örgütlenmesi ve yönetimi. Kuram ve uygulamada eğitim yönetimi, 24(24), 495-508. Retrieved 12, January, 2015, from www.kuey.net/index.php/kuey/article/view/575/388.

Bayrakdar, U., \& Çuhadar, C. (2015). İşitme Engelliler Okullarında Bilgi ve İletişim Teknolojilerinin Öğretim Amaçlı Kullanımının İncelenmesi. Trakya Üniversitesi Ĕ̆itim Fakültesi Dergisi, 5(2). Retrieved 28, April, 2016, from http://dergipark.gov.tr/download/article-file/200418.

Beycioğlu, K., \& Aslan, M. (2010). Okul Gelişiminde Temel Dinamik Olarak Değişim ve Yenileşme: Okul Yöneticileri ve Öğretmenlerin Rolleri. Yüzüncü Yıl Üniversitesi Ĕgitim Fakültesi Dergisi, 7(1). Retrieved 25, January, 2015, from http://dergipark.gov.tr/download/article-file/146285.

Blackorby, J., \& Knokey, A. M. (2006). A national profile of students with hearing impairments in elementary and middle school: A special topic report from the Special Education Elementary Longitudinal Study. Menlo Park, CA: SRI International.

Retrieved 12, January, 2015, from

https://www.seels.net/designdocs/SEELS_HearingIImpairmentReport.pdf. 
Brantlinger, E., Jimenez, R., Klingner, J., Pugach, M., \& Richardson, V. (2005). Qualitative studies in special education. Exceptional children, 71(2), 195-207. DOI: http://dx.doi.org/10.1177/001440290507100205.

Büyüköztürk, Ş., Kılıç Çakmak, E., Akgün, E. A., Karadeniz, Ş., \& Demirel, F. (2010). Bilimsel araştırma yöntemleri (5. Baskı) Ankara: Pegem A Akademi.

Cohen, J. (1996). Computer mediated communication and publication productivity among faculty. Internet Research, 6(2/3), 41-63.

DOI: http://dx.doi.org/10.1108/10662249610127328.

Cole, K. M., Cutler, M. M., Thobro, P., \& Haas, R. (2009). An exploratory study of psychosocial risk behaviors of adolescents who are deaf or hard of hearing: Comparisons and recommendations. American Annals of the Deaf, 154(1), 30-35.

Çalık, T. (2003). Eğitimde değişimin yönetimi; kavramsal bir çözümleme. Kuram ve Uygulamada Eğitim Yönetimi 36, 536-557. Retrieved 18, July, 2015, from www.kuey.net/index.php/kuey/article/view/467/290.

Çalık, T., \& Er, E. (2014). İlköğretim Okulu Öğretmenlerinin Okulun Değişime Açıklığı ile Değişim Kapasitesi Algıları Arasındaki İlişkinin İncelenmesi. Kuram ve Uygulamada Egitim Yönetimi Dergisi, 20(2), 151-172. DOI: http://dx.doi.org/10.14527/kuey. 2014.007

Çiftçi, E. (2009). İşitme engelli öğrenciler için hazırlanan bilgisayar destekli yazılı anlatım becerisi geliştirme materyalinin tasarımı, uygulanması ve değerlendirilmesi. Unpublished Master Thesis. Karadeniz Technical University, Turkey. Available from https://tez.yok.gov.tr/UlusalTezMerkezi/giris.jsp (Thesis No: 238459)

Dillon, C. M., de Jong, K., \& Pisoni, D. B. (2012). Phonological awareness, reading skills, and vocabulary knowledge in children who use cochlear implants. Journal of Deaf Studies and Deaf Education, 17(2), 205-226. DOI: http://dx.doi.org/10.1093/deafed/enr043.

DiPaola, M. F., \& Walther-Thomas, C. (2003). Principals and Special Education: The Critical Role of School Leaders. National Clearinghouse for Professions in Special Education (Report No. COPSSE-IB-7) Arlington, Virginia: Florida University.

Erdoğan, İ. (2012). Eğitimde değişim yönetimi. Ankara: Pegem Akademi. 
Fullan, M. G. (1993). Why teachers must become change agents. Educational leadership, 50, 12-12.

Fullan, M. (1999). Change forces: The sequel (Educational Change and Development Series). London: RoutledgeFalmer.

Fullan, M. (2002). “The Change Leader”, Educational Leadership. 59 (8), p.16. Retrieved from http://michaelfullan.ca/wp-content/uploads/2016/06/13396052090.pdf

Girgin, Ü., Coklar, A. N., Kurt, A. A., \& Odabasi, H. F. (2009). Use of technology as a solution to the problems faced in literacy education by the teachers of the hearing impaired: ISITEK project. In I. International Conference on Computational and Information Science, ABD Houston.

Goddard, J. T., \& Bohac-Clarke, V. (2007). The cycles of school change: Toward an integrated developmental model. The Journal of Educational Thought (JET)/Revue de la Pensée Educative, 105-123.

Goodson, I. (2001). Social histories of educational change. Journal of Educational Change, 2(1), 45-63. DOI: http://dx.doi.org/10.1023/A:1011508128.

Hargreaves, A., \& Fullan, M. (1998). What's Worth Fighting for Out There?. Williston: Teachers College Press.

Harris, A. (2002). School Improvement: What's in it for Schools? New York: RoutledgeFalmer.

Harris, A. (2008). Distributed Leadership. New York: Routledge.

Hopkins, D. (2001) School Improvement for Real. London: Routledge.

Karal, H., \& Çiftçi, E. (2008). İşitme engelli bireylerin eğitim sürecinde bilgisayar destekli animasyonlardan yararlanma. In 8th International Educational Technology Conference, Vol.30, No.08, p.2013. Retrieved 12, January, 2015, from http://ietc2008.home.anadolu.edu.tr/ietc2008/86.doc

Karal, Y., (2014), Alternatif iletişim aracı olarak bir elektronik görsel sözlüğün tasarlanması, uygulanması ve değerlendirilmesi., Unpublished Doctoral Thesis. Karadeniz Technical University, Turkey. Available from https://tez.yok.gov.tr/UlusalTezMerkezi/giris.jsp (Thesis No: 380257) 
Karal, Y , Karal, H , Coşar, A, Altun, T , Şılbır, L , Bahçekapılı, E , Atasoy, M , Palancı, M . (2014). Designing Learning Materials within the Framework of the ALIS-T Project: Story Telling Activities for Hearing Impaired Individuals. Turkish Online Journal of Qualitative Inquiry, 5 (4), 114-128. Retrieved 21, April, 2016, from http://dergipark.gov.tr/tojqi/issue/21405/229419

Karal, H. (2015). The effects of a technology-aided learning environment on the improvement of a primary special education school. Educational Research and Reviews, 10(24), 29082918. DOI: http://dx.doi.org/10.5897/ERR2015.2523

Karchmer, M., \& Mitchell, R. (2003). Demographic and achievement characteristics of deaf and hard-of-hearing students. In M. Marschark \& P. Spencer (Eds.), Oxford handbook of deaf studies, language, and education (pp. 21-37). New York: Oxford University Press.

Kaya, Ö. (2013). Yeni fizik dersi öğretim programının ilk yıllardaki uygulamalarına yönelik deneyimlerin incelenmesi. Unpublished Doctoral Thesis. Karadeniz Technical University, Turkey. Available from https://tez.yok.gov.tr/UlusalTezMerkezi/giris.jsp (Thesis No: 344457)

Kırıkkaya, E. B., Dağ, F., Durdu, L., \& Gerdan, S. (2016). 8. Sınıf Doğal Süreçler Ünitesi İçin Hazırlanan BDÖ Yazılımı ve Akademik Başarıya Etkisi. İlköğretim Online, 15(1). DOI: http://dx.doi.org/10.17051/io.2016.11845

Kondakçı, Y. (2005). Practice-based continuous change process: A longitudinal investigation of an organizational change process in a higher education organization. Unpublished Doctoral Thesis. Ghent University, Belgium.

Kretschmer, R. R., \& Kretschmer, L. W. (1986). Language in perspective. In D. M. Luterman (Ed.), Deafness in perspective (pp. 131-166). San Diego, CA: College-Hill Press.

Lodge, C., \& Reed, J. (2003). Transforming school improvement now and for the future. Journal of Educational Change, 4(1), 45-62.

DOI:https://doi.org/10.1023/A:1023098303107

Marschark, M., Sapere, P., Convertino, C., Mayer, C., Wauters, L., \& Sarchet, T. (2009). Are deaf students' reading challenges really about reading? American Annals of the Deaf, 154, 357-370. DOI: https://doi.org/10.1353/aad.0.0111 
Mayer, C., \& Leigh, G. (2010). The changing context for sign bilingual education programs: Issues in language and the development of literacy. International Journal of Bilingual Education and Bilingualism, 13(2), 175-186.

DOI: https://doi.org/10.1080/13670050903474085

Milne, M. J., \& Adler, R. W. (1999). Exploring the reliability of social and environmental disclosures content analysis. Accounting, Auditing \& Accountability Journal, 12(2), 237256. DOI: https://doi.org/10.1108/09513579910270138

National School Board Association-NSBA. (2003).Education Sytemic Change Tools.

Obiakor, F. E., \& Rotatori, A. F. (Eds.). (2010). Advances in Special Education. Current Issues and Trends in Special Education: Research, Technology, and Teacher Preparation: Research, Technology, and Teacher Preparation (Vol. 20). Bingley: Emerald Group Publishing.

Patton, M. (2002). Qualitative Research and Evaluation Methods, 3rd ed. Thousand Oaks, California: Sage Publication.

Pınar, E. G. E. (2006). Farklı engel gruplarının iletişim özellikleri ve öğretmenlere öneriler. Ankara Üniversitesi Ĕ̈itim Bilimleri Fakültesi Özel Ĕgitim Dergisi, 7(02). DOI: https://doi.org/10.1501/Ozlegt_0000000099

Sağ, V. (2003). Toplumsal değişim ve eğitim üzerine. C.Ü. Sosyal Bilimler Dergisi, 27(1): 1125.

Salvason, C. (2005). Investigating specialist school ethos... or do you mean culture? Educational Studies, 31, 85-94. DOI: https://doi.org/10.1080/0305569042000310985

Schein, E. , (2004). Organizational culture and leadership. (3nd Edition). San Francisco: Jossey-Bass.

Shank, G. D. (2006). Qualitative Research: A Personal Skills Approach (2nd edition). New Jersey: Pearson Merrill Prentice Hall.

Sheehy, G. (1981).Path Finders: How to Achieve Happiness by Conquering Life's Crises. London: Sidgwick \& Jackson. 
Shepherd, C. M., \& Alpert, M. (2015). Using technology to provide differentiated instruction for deaf learners. Journal of Instructional Pedagogies, 16, 1. Retrieved 21, April, 2016, from https://www.aabri.com/manuscripts/152221.pdf

Snoddon, K. (2010). Technology as a learning tool for ASL literacy. Sign Language Studies, 10(2), 197-213. Retrieved 23, July, 2018, from https://www.jstor.org/stable/26190568

Stiggins, R.J. (2002). Assessment crisis: The absence of assessment for learning. Phi Delta Kappan, 83(10), 758-765. DOI: https://doi.org/10.1177/003172170208301010

Şılbır, L. (2011). İşitme Engelli Öğrencilerin Türkçe Okuma Yazma Becerilerinin Geliştirilmesine Yönelik Görsel Yardım Paketi: GÖRYAP. Unpublished Master Thesis. Karadeniz Technical University, Turkey. Available from https://tez.yok.gov.tr/UlusalTezMerkezi/giris.jsp (Thesis No: 298677)

Turnbull, A., Turnbull, H. R., Wehmeyer, M. L., \& Shogren, K. A. (2013). Exceptional lives: Special education in today's schools. Columbus, Ohio: Pearson.

Tüfekçioğlu, U. (1998). Farklı eğitim ortamlarındaki işitme engelli öğrencilerin konuşma dillerinin incelenmesi. Eğitim ve Bilimsel Araştırma Çalışmaları Vakfi Yayınları.

Underwood, J. D., \& Underwood, G. (1990). Computers and learning: Helping children acquire thinking skills. Massachusetts: Blackwell.

Uzuner, Y., Icden, G., Girgin, U., Beral, A., \& Kircaali-Iftar, G. (2005). An Examination of Impacts of Text Related Questions on Story Grammar Acquisition of Three Turkish Youths with Hearing Loss. International Journal of Special Education, 20(2), 111-121. Retrieved from http://www.internationalsped.com/issues.cfm

Uzuner, Y., Girgin, Ü., Kaya, Z., Karasu, G., Girgin, M. C., Erdiken, B., Cavkaytar, S., \& Tanrıdiler, A. (2011). İşitme engelli gençlere uygulanan dengeli okuma yazma öğretimi modelinin incelenmesi. Kuram ve Uygulamada Eğitim Bilimleri, 11(4), 2111-2132. DOI: https://doi.org/10.21565/ozelegitimdergisi.310350

Yalçın Tepe, F. D. (2015). Eğitim kurumlarında teknoloji ile değişim süreci: bir yükseköğretim kurumu örneği, Unpublished Master Thesis. Bahçeşehir University, Turkey. Available from https://tez.yok.gov.tr/UlusalTezMerkezi/giris.jsp (Thesis No: 414603)

Yıldırım, A., \& Şimşek, H. (2005). Sosyal bilimlerde nitel araştırma yöntemleri. Ankara: Seçkin Yayıncılık. 